\title{
Characterization of a temperate bacteriophage of Lactobacillus delbrueckii subsp. bulgaricus and its interactions with the host cell chromosome
}

\author{
Y. Lahbib-Mansais, $\uparrow$ B. Boizet, L. Dupont, M. Mata and P. Ritzenthaler* \\ Centre de Recherche de Biochimie et de Génétique Cellulaires du CNRS, 31062 Toulouse, France
}

(Received 25 October 1991; revised 4 February 1992; accepted 2 March 1992)

\begin{abstract}
The temperate bacteriophage mv4 is representative of a widespread phage genetic group of Lactobacillus delbrueckii subsp. lactis or bulgaricus. The genome of this phage is circularly permuted and terminally redundant, as shown by mature mv4 homoduplexes, Southern hybridization and restriction enzyme analysis. A circular map of the mv4 genome was established, with unique sequences totalling $36 \mathrm{~kb}$. The genomic location of the pac site (packaging site of mv4 DNA into phage heads) and the att site (phage integration site into the host cell chromosome) was determined. The genes coding for the two main structural phage proteins and for a phageassociated lysin were also mapped. Phage mv4 is capable of transducing a limited set of pieces of bacterial DNA and several specific chromosomal attachment sites of phage $\mathrm{mv} 4$ were identified. Bacteria lysogenic for phage mv4 were shown to be immune to infection by $L$. delbrueckii virulent phages related to mv4.
\end{abstract}

\section{Introduction}

Lactobacillus delbrueckii subsp. bulgaricus is a member of the large and economically important genus Lactobacillus (Kandler \& Weiss, 1986), and is found predominantly in fermented milk products, being used as a starter culture for yoghurt and cheese production. It is a fastidious bacterium, growing only in rich growth media. Despite the use of $L$. delbrueckii subsp. bulgaricus for hundreds of years, very little is known about its genetic properties, and to date, no efficient gene transfer system has been described for it (Langella \& Chopin, 1987; Boizet et al., 1988). The only genes isolated and analysed so far are the $\beta$-galactosidase gene (Schmidt et al., 1989; Mollet \& Delley, 1990; Mollet \& Delley, 1991) and several tRNA genes (Hottinger et al., 1987; Pittet \& Hottinger, $1989 a, b$; Schön et al., 1988), which reveal original features concerning genetic stability and translation mechanisms.

An alternative way to study the genetics of this bacterial species is through its bacteriophages and their interactions with the host cell. As in other bacterial genera, bacteriophages may serve as an important model system for basic molecular genetic studies and may be

\footnotetext{
* Author for correspondence. Tel. 61559 657; fax 61559500.

† Present address: INRA, B.P. 27, Chemin de Borde Rouge, 31326 Castanet-Tolosan Cédex, France.
}

useful tools for molecular cloning or gene transfer. In addition, in the dairy industry, bacteriophage contamination of the starter strains is a common occurrence, and is an important problem affecting yoghurt and cheese manufacturing processes. A detailed knowledge of the biology of these phages will facilitate the improvement of phage resistance of $L$. delbrueckii subsp. bulgaricus starter cultures.

In previous work (Lahbib-Mansais et al., 1988; Mata et al., 1986), phages of $L$. delbrueckii subsp. bulgaricus were differentiated into two DNA homology groups. The most widespread group, designated group $a$, contained 15 virulent and 4 temperate phages. The genome of one virulent phage of this group has been characterized (Trautwetter et al., 1986). The two temperate phages belonging to group $a$ (mv1 and $\mathrm{mv} 4)$ are closely related (Mata et al., 1986), and their ultrastructural morphology has been described (Cluzel et al., 1987). We have initiated the study of temperate phage mv4, and characterized the lys $A$ gene, which encodes an endolysin, at a molecular level (Boizet et al., 1990). We intend to use this phage as a model system to study lysogeny in Lactobacillus delbrueckii subsp. bulgaricus and possibly to develop it into a gene transfer and integration system for L. delbrueckii subsp. bulgaricus. In the present paper, we report the characterization of the genome of phage $\mathrm{mv} 4$ and the interrelationships of phage mv4 with the host chromosome. 


\section{Methods}

Bacterial strains, plasmids and bacteriophages. Escherichia coli strains HB101 pro leu rpsL hsdR gal thi recA lacY (Boyer \& Roulland-Dussoix, 1969) and MC1061 araD139 $\Delta$ (ara-leu)7697 $\Delta$ lacX74 galU hsdR rpsL sup $^{\circ}$ (Minton, 1984) were used for the transformation experiments and $\mathrm{K} 38$ (HfrC) (Russel \& Model, 1984) for the in vivo expression experiments. E. coli plasmids used were pBR322 (Bolivar et al., 1977), pTZ18R and pRZ19R (Mead et al., 1986) and pGP1-2 (Tabor \& Richardson, 1985). We used $L$. delbrueckii subsp. bulgaricus temperate phages mv1, mv4, $\$ 37$ and $\Phi 38$ (Cluzel et al., 1987; Lahbib-Mansais et $a l ., 1988$ ) and $L$. delbrueckii subsp. lactis and bulgaricus virulent phages P1, P18, Ф50, Ф51, and $\Phi 52$ (Lahbib-Mansais et al., 1988; Mata et al., 1986). LT4 and LT1 were Lactobacillus delbrueckii subsp. bulgaricus strains lysogenic for phages mv4 and mvl respectively (Cluzel et al., 1987). Lactobacillus delbrueckii subsp. lactis LKT was the propagating host for both temperate phages mv4 and mv1. LT4-31, LT4-32 and LT4-33 were independently isolated derivatives of LT4 cured of its prophage by mitomycin C treatment (this study). LKT was lysogenized with phages mvl and mv4. Four independently isolated lysogenic strains were obtained: LKT6 and LKT7 contained prophage mv1 and LKT8 and LKT9 contained prophage mv4 (this study). Lactobacillus delbrueckii was grown in MRS broth (De Man et al., 1960).

DNA isolation and manipulation. Plasmid DNA isolation, restriction endonuclease digests, DNA ligation, gel electrophoresis and $E$. coli transformation were performed as described by Sambrook et al. (1989).

DNA-DNA hybridization. Purified phage DNAs were digested with endonucleases and electrophoresed on a $1 \%$ or $0.7 \%$ agarose gel. The resulting fragments were transferred to nylon sheets (Hybond-N, pore size, $0.45 \mu \mathrm{m}$; Amersham) as described by Southern (1975) and modified by Reed \& Mann (1985) (vacuum blot technique). The filter sheets were then incubated at $42^{\circ} \mathrm{C}$ for $24 \mathrm{~h}$ in hybridization buffer containing ${ }^{32} \mathrm{P}$-labelled reference DNA obtained by nick translation (Rigby et al., 1977) or random priming (Feinberg \& Vogelstein, 1983). Hybridization buffer was $50 \%(\mathrm{v} / \mathrm{v})$ formamide in $6 \times$ SSC $(1 \times$ SSC is $0.15 \mathrm{M}-\mathrm{NaCl}$ plus $0.015 \mathrm{M}$-sodium citrate) $/ 0.1 \%$ SDS/5 mM-EDTA/ $2.5 \%(\mathrm{w} / \mathrm{v})$ fat-free milk powder (Johnson et al., 1984). After hybridization, the strips were sequentially washed in (i) $2 \times \mathrm{SSC} / 0.1 \% \mathrm{SDS}$ at room temperature for $30 \mathrm{~min}$ (twice) and (ii) $0.2 \times \mathrm{SSC} / 0.1 \% \mathrm{SDS}$ at $55^{\circ} \mathrm{C}$ for $30 \mathrm{~min}$ (twice); the filter was dried after the final wash and exposed to Kodak XAR film.

Pulsed-field gel electrophoresis. Genomic DNA of the lysogenic or cured strains was prepared by the method of McClelland et al. (1987). The agarose plugs containing the chromosomal DNA were incubated at the appropriate temperature for 8 to $16 \mathrm{~h}$ in the presence of 10 to 25 units of the restriction enzyme. Oligomers of phage $\lambda$ were prepared by the Waterbury method (Waterbury \& Lane, 1987). Electrophoresis of the DNA was done on a contour-clamped homogeneous electric field system (Pulsaphor Plus; LKB Pharmacia) for 7 to $14 \mathrm{~h}$ in TBE (50 mMTris base, $50 \mathrm{~mm}$-boric acid, $1 \mathrm{~mm}$-EDTA), with two different pulse times: $1 \mathrm{~s}$ for phage or $2.5 \mathrm{~s}$ for cells, at $200 \mathrm{~V}$, as previously described (Le Bourgeois.et al., 1989). To eliminate the extrachromosomal form of mv4 DNA present in the lysogens, the agarose plugs containing the lysed cells were subjected to pre-electrophoresis in standard conditions $(0.8 \%$ agarose, $1 \mathrm{~h}, 60 \mathrm{~V})$.

Cloned gene expression by the in vivo transcription/translation technique. E.coli K38 with plasmid pGP1-2 (coding for T7 RNA polymerase under $\lambda c 1857, \lambda p \mathrm{~L}$ control) was transformed with plasmids $\mathrm{pTZ18R}$ or pTZ19R containing mv4 DNA fragments. The proteins encoded by these recombinant plasmids were labelled with $L-\left[{ }^{35} S\right]$ methionine after heat induction as outlined by Tabor \& Richardson (1985), separated by SDS-PAGE and detected by autoradiography.
Immunoblotting. Immunoblotting experiments were performed as described earlier (Mata et al., 1986).

\section{Results}

Phage sensitivity of prophage-cured and lysogenic strains

The two Lactobacillus delbrueckii subsp. bulgaricus strains LT4 and LT1 were shown to be lysogenic for phage mv4 and mv1 respectively (Cluzel et al., 1987). Both induced phages could be propagated on Lactobacillus delbrueckii subsp. lactis strain LKT. When phage mv4 was propagated on this strain, the latent period of the phage was $60 \mathrm{~min}$ and the burst size was 45 phages per cell. The lysogenic strain LT4 was cured of its prophage by mitomycin $\mathrm{C}$ treatment, and conversely the indicator strain LKT was lysogenized by mv4 or mvl. Phages P1, $P 18, \Phi y, \Phi 50, \Phi 51$ and $\Phi 52$ isolated as virulent phages, as well as the two temperate phages $\Phi 37$ and $\Phi 38$, are related to phage mv4 (Lahbib-Mansais et al., 1988). The lysogenic and prophage-cured strains were examined for their sensitivity to all of these phages. All of them were able to propagate on prophage-cured strain LT4 and on strain LKT. In contrast, the lysogenic strains LT4, LKT6, LKT7, LKT8, LKT9 were resistant to all the phages tested. The phage adsorption measured with phage mv4 reached 85 to $95 \%$ for the lysogenic or the cured strains, proving that the phage resistance did not occur at the adsorption level. Therefore, the prophages mv1 and mv4 are capable of conferring superinfection immunity not only to mvl or mv4 infection but also to that of other mv4 related phages.

\section{Restriction map of phage mv4}

Electron micrographs of mv4 DNA showed linear molecules with an estimated size of $38.7 \mathrm{~kb}$ (results not shown). Several restriction enzymes were used to digest mv1 and mv4 DNAs. The phage genomes were not cut by NotI, ApaI or SgrA1. Only minor variations in the restriction patterns of phages $\mathrm{mv} 1$ and mv4 were observed. For example, the $S a I I$ and $P s t I$ digests differed only by one or two fragments. The $10.5 \mathrm{~kb}$ SalI-C fragment of mv4 (Fig. 1) was absent in the pattern of $\mathrm{mvl}$, and two additional bands of 8.25 and $2.25 \mathrm{~kb}$ appeared, suggesting that the $10.5 \mathrm{~kb}$ SalI fragment contained an additional site in the mvl genome with respect to the mv4 genome. This was confirmed by DNA-DNA hybridization, since the $10.5 \mathrm{~kb}$ SalI fragment was able to hybridize to both the $8.25 \mathrm{~kb}$ and the $2.25 \mathrm{~kb}$ Sall fragments of mv1 DNA. The $3.5 \mathrm{~kb}$ Pst I-E restriction fragment in the mv4 digest (Fig. 1) was absent in that of mvl and was replaced by a $2.7 \mathrm{~kb}$ fragment. 


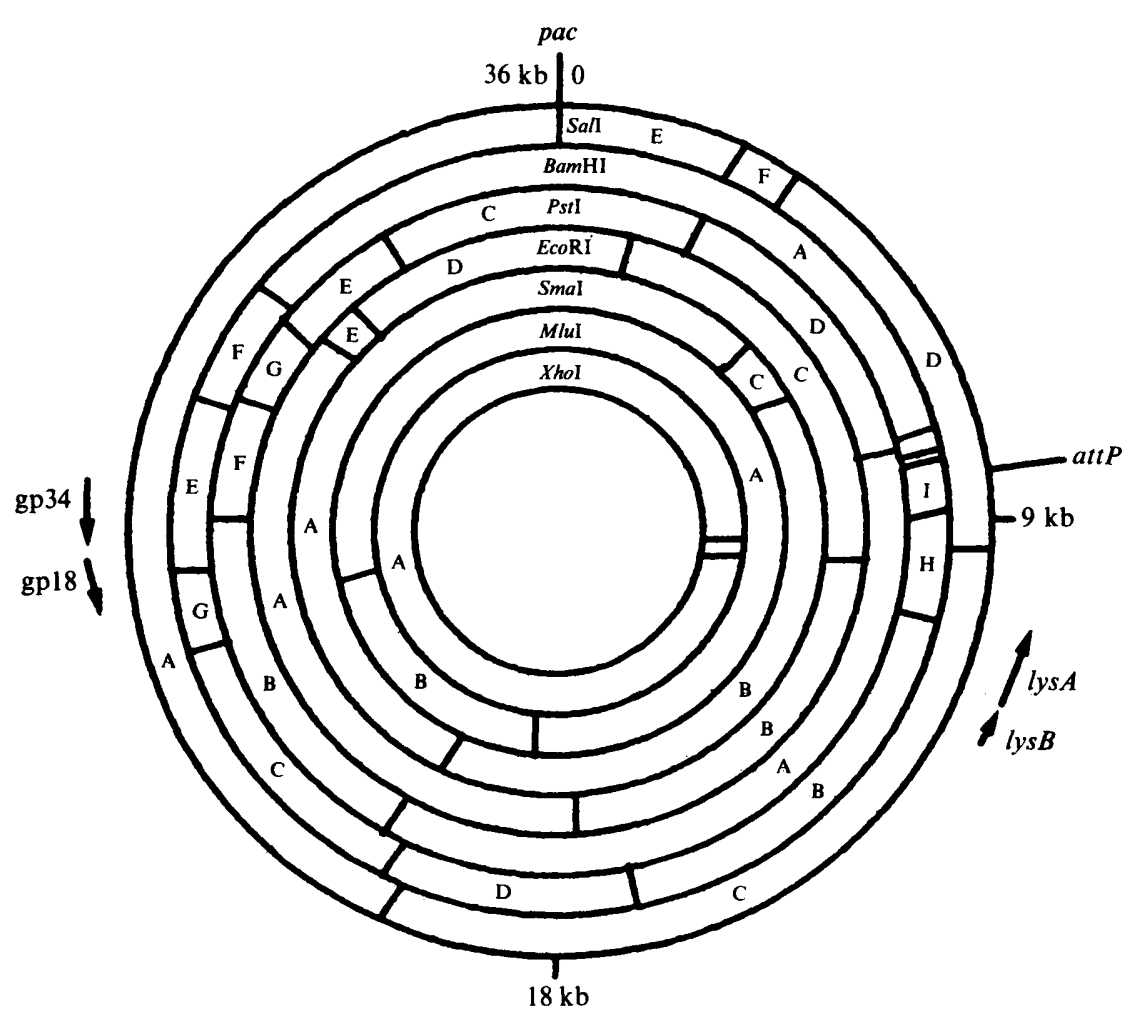

Fig. 1. Circular restriction map of phage mv4 DNA. The size of the map is given in $\mathrm{kb}$, starting from pac, the site of initiation of the first round of DNA packaging into the heads. The locations of pac and attP, the attachment site of the phage into the host chromosome, are marked. The genes coding for the two major structural phage proteins of 18 and $34 \mathrm{kDa}$ and the operon involved in the cell lysis (lysB-lysA) are shown on the map, and their direction of transcription is indicated by an arrow.

These two fragments were able to hybridize in Southern blot experiments. A deletion of $0.8 \mathrm{~kb}$ had probably occurred in the $2.7 \mathrm{~kb}$ Pst I fragment of mvl. The genome sizes of mv4 and mvl were estimated from the size of the restriction fragments as 36 and $35 \cdot 2 \mathrm{~kb}$. The phages seemed to have a common origin.

To facilitate the construction of a restriction map and to study the phage genome expression, EcoRI, PstI, SalI and BamHI restriction fragments of mv4 were cloned into $E$. coli plasmid vectors. About $95 \%$ of the phage genome was cloned. A restriction map of the mv4 genome was constructed from data obtained with single and double digests of mv4 DNA, by comparing the restriction patterns of mv4 to that of the cloned fragments and by hybridization studies with recombinant plasmids to probe digests of mv4 DNA. The BamHI, EcoRI, MluI, PstI, SalI, SmaI and XhoI restriction maps deduced from these experiments are shown in Fig. 1.

The configuration of mv4 genome extremities was examined. It seems likely that phage mv4 does not possess cohesive ends. Heating at $65^{\circ} \mathrm{C}$ before electrophoresis or incubation in conditions allowing cohesive ends to anneal did not alter the restriction pattern of EcoRI, PstI, SalI or BamHI digested mv4 DNA, and the method used for generating concatemers of phage $\lambda$ (Waterbury \& Lane, 1987) failed to produce concatemers of phage mv4. The fragments located at the two extremities of the linear phage genome could not be determined. For example, each restriction fragment generated by $E c o$ RI digestion was flanked on either side by another EcoRI fragment as deduced from DNADNA hybridization experiments. These observations are consistent with a circular restriction map, indicating that individual mv4 molecules are terminally redundant, the molecules differing in their sequence by a circular permutation. This result was confirmed by analysis of electron micrographs of homoduplexes of the mature mv4 DNA. Circular molecules were observed with single-stranded tails at opposite positions (Fig. 2). The efficient circle formation clearly indicates the presence of terminally redundant circularly permuted DNA sequences in a population of $\mathrm{mv} 4$ molecules.

\section{Site of initiation of genome packaging}

As seen on electron microscopy and in Fig. 3 (lane 7), all the linear mv4 DNA molecules seemed to be homogeneous in size. However, fine analysis of phage DNA 


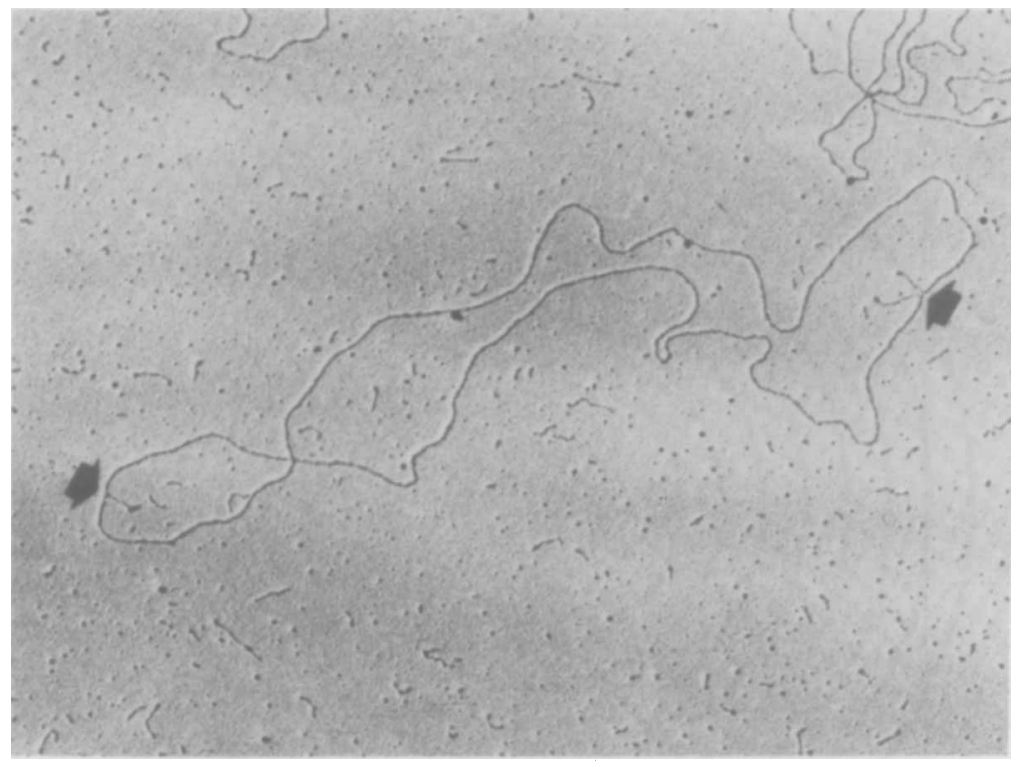

Fig. 2. Homoduplex analysis of phage mv4 DNA. The arrows point to single-stranded terminal repetitions.

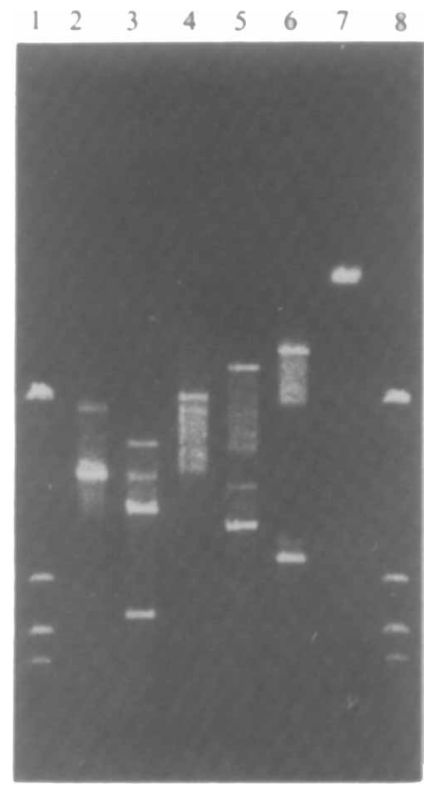

Fig. 3. Restriction patterns of phage mv4 DNA on pulsed-field gel electrophoresis, using a $1 \mathrm{~s}$ pulse. Lanes 1 and 8 contain $E c o$ RI-digested $\lambda$ DNA $(24 \cdot 7,21 \cdot 0,7 \cdot 4,5 \cdot 8$ and $5 \cdot 6 \mathrm{~kb})$. Phage mv4 DNA was digested with SmaI (lane 2), SalI (lane 3), XhoI (lane 4), SfiI (lane 5), MluI (lane 6), undigested mv4 DNA (lane 7).

restriction patterns revealed some unusual characteristics. The presence of submolar fragments was often detected. In addition to the 5 major fragments, one minor band of $12.5 \mathrm{~kb}$ (Sall-B, Fig. 3, lane 3) was always visible in the SalI digests, and sometimes faint bands of 3.4 and $6.7 \mathrm{~kb}$ appeared. The submolar $12.5 \mathrm{~kb}$ Sall-B fragment shows homology with the $16 \mathrm{~kb} S a l \mathrm{I}-\mathrm{A}$ fragment, indicating that Sall-B is obviously derived from the SalIA well-defined larger fragment. These submolar fragments were also particularly well visible in restriction patterns obtained with enzymes having few cutting sites on the mv4 chromosome like SmaI (3 sites), XhoI (2 sites), MluI (2 sites) and SfiI (2 sites) (Figs. 1 and 3 ).

Endonuclease $X h o I$ has two cleavage sites on the mv4 genome which are $0.5 \mathrm{~kb}$ distant. Instead of two fragments of well-defined size in addition to the $0.5 \mathrm{~kb}$ $X$ hoI fragment, a smear running from 26 to $13 \mathrm{~kb}$ was detected (Fig. 3, lane 4). The MluI and SfiI patterns were characterized by a central fragment of 8 and $10 \mathrm{~kb}$ respectively, and two smears ( 31 to $24 \mathrm{~kb}$ and 9 to $6 \mathrm{~kb}$ for MluI, 28 to $18 \mathrm{~kb}$ and 15 to $8 \mathrm{~kb}$ for $S f \mathrm{I})$ corresponding to the two extremity fragments, which have a variable length. The sum of all fragment sizes, including all faint bands, exceeds the genome length by at least twofold.

All these results suggest that the submolar fragments are generated during maturation of the phage genome. Phage DNA replication generates DNA concatemers. These molecules are cleaved at a unique pac site located at the SalI-A-SalI-E junction (Fig. 1) before packaging in the phage head. The predicted direction of packaging is counterclockwise on the map shown in Fig.1. The first round of packaging should give rise to a mv4 DNA molecule with a terminal redundancy of about $3.5 \mathrm{~kb}$ and subsequent rounds of packaging would follow. 
For example, the $26 \mathrm{~kb} X h o \mathrm{I}$ and $9 \mathrm{~kb} M l u \mathrm{I}$ faint bands observed correspond to the distance between the pac site and the next restriction site in a counterclockwise direction in the restriction map, during the processing of the first unit molecule. The $23 \mathrm{~kb}$ XhoI and $12.5 \mathrm{~kb}$ SalI minor bands are probably generated during the processing of the second unit molecule.

The submolar fragments should not be present in the prophage since they are produced during the maturation of the phage genome. This hypothesis was confirmed by DNA-DNA hybridization studies. In Southern blots of SalI, BamHI, MluI and XhoI digests of bacterial genomic DNA from the lysogenic strain LT4, only the major bands hybridized to mv4 DNA. The faint bands and the smears gave no hybridization signal, proving that they were produced only after induction of the prophage.

\section{Expression of the phage mv4 genome}

The molecular masses of the structural proteins of phage mv4 as estimated by SDS-PAGE were $68,61,46,34$ and $18 \mathrm{kDa}$. The 18 and $34 \mathrm{kDa}$ proteins gave very intense bands, and probably correspond to the major proteins of the tail and the capsid. To localize the genes coding for these structural proteins on the mv4 genome, three methods were used. First, in immunoblot analysis, among all the mv4 recombinant plasmids, only those containing the Pst $\mathrm{I}-\mathrm{B}$ fragment produced an $18 \mathrm{kDa}$ protein in $E$. coli able to react with polyclonal rabbit antiserum to phage mv4. This protein is one of the major phage proteins. No other protein could be detected by this procedure.

Phage mv4 is related to LL-H, a virulent phage of Lactobacillus delbrueckii subsp. lactis, at both DNA and protein levels (Mata et al., 1986). A bank of LL-H restriction fragments previously constructed and characterized (Trautwetter et al., 1986) was used to locate the structural genes on the mv4 restriction map. Plasmid pTHS41 coding for a $34 \mathrm{kDa}$ LL-H protein was able to hybridize to fragment PstI-F of mv4. DNA homology was also found with plasmid pTHE1 coding for the 19 and $34 \mathrm{kDa}$ LL-H proteins and the PstI-B, EcoRI-A, BamHI-E, BamHI-G and SalI-A mv4 restriction fragments. Plasmid pTHP2 coding for LL-H-phage-associated lysin and for 54 and $75 \mathrm{kDa}$ proteins hybridized to EcoRI-B, SalI-C, PstI-A, BamHI-B and BamHI-D mv4 fragments. To identify the mv4 gene products more accurately, an in vivo transcription/translation expression study was performed, using the system of Tabor \& Richardson (1985). Some of the mv4 restriction fragments able to hybridize to the LL-H structural genes were cloned into the expression vector $\mathrm{pTZ18R}$ or pTZ19R in opposite orientations with respect to the T7
Table 1. In vivo expression of mv4 cloned genes by $T 7$ RNA polymerase promoter expression system

E. coli K38(pGP1-2) cells transformed with pTZ18R or pTZ19R containing mv4 inserts were labelled with $\mathrm{L}-\left[{ }^{35} S\right]$ methionine as described in Methods.

\begin{tabular}{lccc}
\hline \hline & Insert & & \\
\hline Designation & Size (kb) & $\begin{array}{c}\text { Direction of } \\
\text { transcription* }\end{array}$ & $\begin{array}{c}\text { Size of } \\
\text { synthesized } \\
\text { proteins (kDa) }\end{array}$ \\
\hline PstI-B & $6 \cdot 7$ & +1 & none \\
PstI-B & $6 \cdot 7$ & -1 & $18-27 \cdot 5$ \\
PstI-F & $2 \cdot 4$ & +1 & none \\
PstI-F & $2 \cdot 4$ & -1 & $39-20$ \\
BamHI-E & $3 \cdot 2$ & +1 & none \\
BamHI-E & $3 \cdot 2$ & -1 & 34 \\
\hline \hline
\end{tabular}

* Direction of insert transcription with respect to the restriction map (Fig. 1): +1, clockwise; -1 , anticlockwise.

promoter site of the plasmid. E. coli $\mathrm{K} 38$ containing plasmid pGP1-2, which expresses a T7 RNA polymerase under temperature control was transformed with the pTZ derivatives carrying mv4 fragments. Under the appropriate expression conditions, the double transformant cells produced polypeptides of different sizes, depending on the nature and the orientation of the cloned fragment in the pTZ vector (Table 1). In all cases, only one orientation of the phage inserts into pTZ plasmid gave rise to the synthesis of proteins, proving that there is only one coding strand on these fragments. Only two proteins (of 18 and $34 \mathrm{kDa}$ ) synthesized in the in vivo transcription/translation expression system comigrated with the two major structural proteins of phage mv4. The other proteins synthesized, which did not comigrate with any structural protein of phage mv4, were not identified. The gene $l y s A$ coding for a phageassociated lysin was localized on a $1150 \mathrm{bp}$ fragment within the BamHI-B fragment (Boizet et al., 1990). The location and the direction of transcription of the lysin operon (lysA-lysB) and the genes coding for the two major structural proteins are shown in Fig. 1.

\section{Evidence for the presence of bacterial DNA in the mv4 phage preparations}

To be capable of generalized transduction, a phage must package the DNA from long molecules by the headful. A further requirement for packaging of chromosomal DNA is that the DNA survives intact during phage development. Phage mv4 seems to fulfil these conditions. To determine whether mv4 could transduce chromosomal DNA, purified genomic DNA from strain LKT was used as probe to hybridize to uncut and digested DNA 

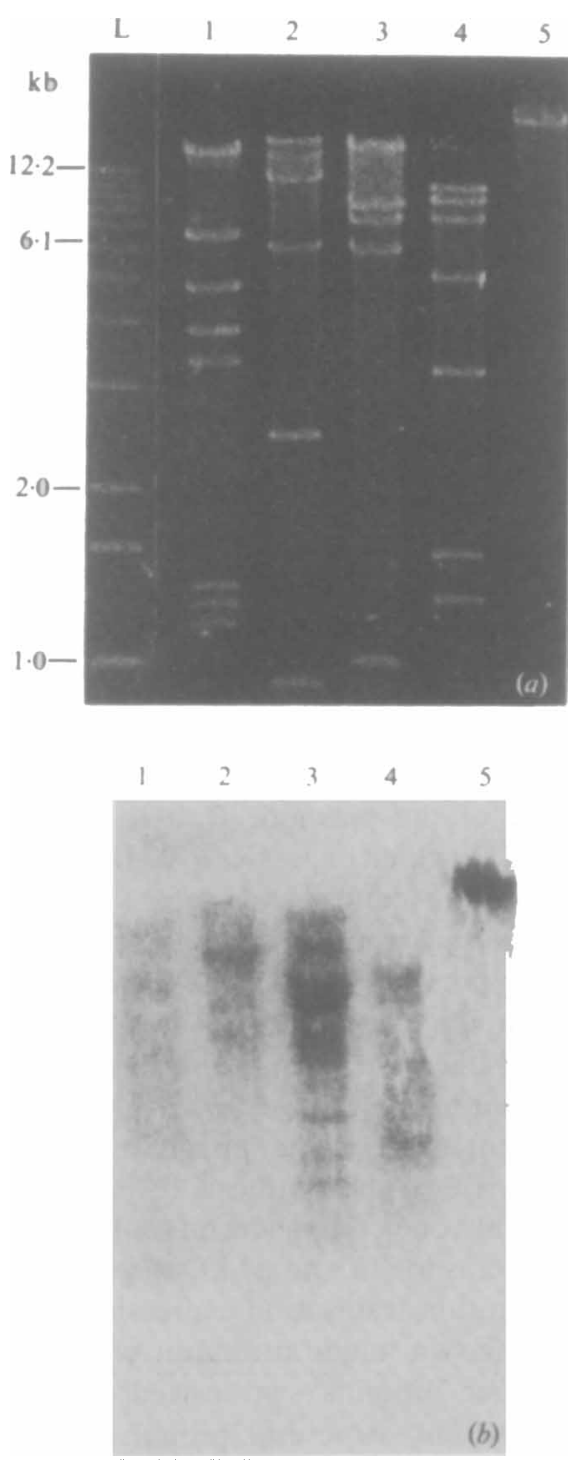

Fig. 4. (a) Agarose gel electrophoresis of endonuclease-digested phage mv4 DNA. (b) Corresponding autoradiography after Southern blot and hybridization with the genomic ${ }^{32} \mathrm{P}$-labelled DNA of the propagating host LKT. Lane L contains a DNA ladder (BRL). Phage mv4 DNA was digested with BamHI (lane 1), SalI (lane 2), EcoRI (lane 3), PvuII (lane 4) and undigested mv4 DNA (lane 5).

from phage mv4 propagated on LKT (Fig. 4). The uncut mv4 DNA gave a significant hybridization signal, whereas weaker bands appeared in the BamHI, EcoRI, SalI and PvulI digest DNAs. These hybridization bands did not comigrate with phage mv4 restriction fragments and were visible only on the autoradiogram. To eliminate the possibility that the hybridization signals were due to contaminant chromosomal DNA from the propagating host LKT, the phage-containing samples were pretreated with DNAase before DNA extraction of the phage.

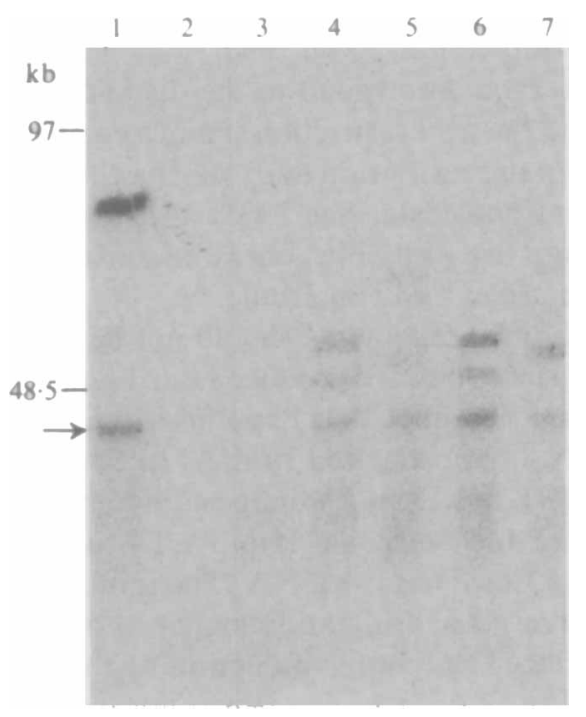

Fig. 5. Southern analysis of a pulsed-field gel electrophoresis of NotIdigested DNA from lysogenic and cured strains. Running conditions were $270 \mathrm{~V}$ for $8 \mathrm{~h}$ with a $2.5 \mathrm{~s}$ pulse time at $12^{\circ} \mathrm{C}$. The radioactive probe was phage mv4 DNA. Lanes: 1 , strain LT4; 2, LT4 cured of mv4; 3, strain LKT; 4, lysogenic strain LKT6; 5, LKT7; 6, LKT8; 7, LKT9. The position of the linear extrachromosomal mv4 DNA is indicated by an arrow.

After DNA-DNA hybridization with LKT genomic DNA, the same bands were apparent for pretreated or untreated phage DNA samples, proving that the bands correspond to LKT genomic DNA packaged into the phage head.

\section{Identification of the phage and bacterial attachment sites}

After NotI digestion, total genomic DNAs of the lysogenic strains LT4, LKT6, LKT7, LKT8 and LKT9 were subjected to pulsed-field gel electrophoresis and hybridized with the mv4 genome as a probe. In addition to one band comigrating with mv4 DNA, other fragments were detected (Fig. 5). An $85 \mathrm{~kb}$ NotI fragment gave a signal in the LT4 DNA digest, whereas two bands (with estimated sizes of 59 and $52 \mathrm{~kb}$ ) hybridized in LKT6 and LKT8 Not I digests and two bands (of approximately 73 and $56 \mathrm{~kb}$ ) were detected in digests of LKT7 and LKT9. Since phage mv4 had no NotI restriction site, strain LT4 contained one attachment site located on a $49 \mathrm{~kb} N o t I$ fragment whereas strain LKT contained at least four distinct mv4 integration sites located on 16, 20,23, and $37 \mathrm{~kb}$ NotI fragments. The attachment sites of phages mv4 and mvl were identical in strain LKT since LKT6 and LKT7 lysogenic for phage mv1 behaved, respectively, as LKT8 and LKT9, which contained mv4 prophages. 
To locate the attachment site on the phage genome, the attP site, mv4 DNA was used as probe to hybridize to phage mv4 or LT4 genomic DNA, both digested with Sall. The LT4 genomic DNA was submitted before SalI restriction to a pre-electrophoresis to eliminate the nonintegrated mv4 genomes present in the preparation. When compared to the mv4 SalI restriction pattern, a phage fragment of $5.9 \mathrm{~kb}$ had disappeared, and two new bands of 8.0 and $2.8 \mathrm{~kb}$ gave a signal in the LT4 DNA digest. Similar results were obtained with $P v u I I$ and $C l a I$ LT4 digests. In each case, one phage fragment disappeared (PvuII, $5.0 \mathrm{~kb}$; ClaI, $4.4 \mathrm{~kb}$ ) but only the $6.5 \mathrm{~kb}$ $P v u I I$ junction fragment was visible (results not shown). The other junction fragments were not detected; either they contained too little DNA homologous to the mv4 probe to produce a signal, or they were masked by the other prophage restriction fragments. Since the phage mv4 integration site in strain LT4 is present on the SalI $5.9 \mathrm{~kb}, \mathrm{PvuII} 5.0 \mathrm{~kb}$ and ClaI $4.4 \mathrm{~kb}$ phage fragments and since these fragments contain a $0.5 \mathrm{~kb}$ overlap, the attP site can be located on this segment on the restriction map (Fig. 1).

\section{Discussion}

Mature mv4 homoduplexes, hybridization studies and restriction enzyme analysis showed that mv4 DNA molecules are terminally redundant and circularly permuted. One of the best known bacteriophages with these features is Salmonella phage P22 (Jackson et al., 1978). A variety of other phages, such as Bacillus subtilis phage SPP1 (Deichelbohrer et al., 1982), Escherichia coli phage P1 (Sternberg \& Coulby, 1987), Lactococcus lactis phage BK5-T (Lakshmidevi et al., 1988) and mycoplasma virus L3 (Just \& Klotz, 1990) support the P22 model: phage DNA packaging occurs by processive 'headful' packaging starting with concatemeric precursor DNA molecules. These replicative intermediates are cleaved at the unique pac site (Casjens et al., 1987). Subsequent rounds of packaging follow. The size and the position of the submolar restriction fragments suggest that the mv4 pac site is located at the SaII-A-SalI-E junction. The predicted direction of packaging is counterclockwise. The mv4 DNA molecule packaged in the phage head would have a terminal redundancy of about $3.5 \mathrm{~kb}$. This feature explains the difference of about $3.5 \mathrm{~kb}$ observed in the mv4 genome size determination when calculated by adding the size of the equimolar restriction fragments $(36 \mathrm{~kb})$ or when measured on entire linear DNA molecules by electron microscopy $(38.7 \mathrm{~kb})$ or by PFGE $(39 \mathrm{~kb})$.

Location of the attachment site (attP) of mv4 DNA on the phage genome and evidence for several specific attachment sites (attB) on the chromosomes of independently isolated lysogens suggest that mv4 DNA could integrate into the bacterial chromosome according to the model of Campbell (1962). Before phage integration, circularization of the linear phage DNA should occur through recombination between the terminally redundant ends as observed for P22 (Weaver \& Levine, 1977) or suggested for phage BK 5-T (Lakshmidevi et al., 1988).

A linear extrachromosomal form of mv4 DNA seemed to co-exist with the prophage integrated form since in Southern blots of DNA from the lysogenic strains, a strong signal corresponding to linear extrachromosomal mv4 DNA was observed. Other hybridization signals due to the prophage could not be detected efficiently without submitting the genomic lysogen DNA preparations to a pre-electrophoresis which eliminates the nonintegrated mv4 DNA (see Methods, pulsed-field gel electrophoresis). Spontaneous induction of the prophage in a part of the lysogenic cell population could explain the presence of this linear extrachromosomal mv4 DNA, but there was no evidence for a high level of virions in lysogenic cultures. The presence of this DNA could also reflect some interesting 'non-standard' feature of this phage's lifestyle and more experiments will be done to clarify this issue.

Some chromosomal regions seem to be overrepresented in mv4 transducing particles as seen in Southern blot hybridization of the bacterial DNAs packaged in the mv 4 capsid. Probably, as suggested for P22 transduction, preferential packaging of particular parts of the cell chromosome occurs from sites resembling pac (Chelata \& Margolin, 1974; Masters, 1985). In contrast, in P1 transducing particles, all bacterial DNA sequences are present in approximately equal amounts (Masters, 1985). The genes coding for the two major proteins of 18 and $34 \mathrm{kDa}$ and for a phage-associated lysin were mapped. They are transcribed in a counterclockwise direction on the restriction map.

The mv1 and mv4 lysogens were shown to be immune not only to phages mvl and mv4 but also to eight Lactobacillus delbrueckii subsp. bulgaricus phages related to mv4. These phages isolated as virulent phages are genetically related to phage mv4 and are probably mv4 derivatives which have inactive gene(s) involved in the phage gene regulation during lysogeny. These genes can be complemented by the corresponding mv4 prophage genes.

This work was supported in part by grants from the Centre National de la Recherche Scientifique (L.P. 8201 and action 'Bactéries Lactiques' du programme Biotechnologies) and from the CEC BRIDGE program. One of us (L.M.Y.) was supported by a BDICNRS/Région Midi-Pyrénées. We thank J. Meyer for the homoduplex analysis, C. Muchard for his help during a stay in the laboratory and $M$. Coddeville for excellent technical assistance. 


\section{References}

Boizet, B., Flickinger, J. L. \& Chassy, B. M. (1988). Transfection of Lactobacillus bulgaricus protoplasts by bacteriophage DNA. Applied and Environmental Microbiology 54, 3014-3018.

Boizet, B., Lahbib-Mansais, Y., Dupont, L., Ritzenthaler, P. \& MatA, M. (1990). Cloning, expression and sequence analysis of an endolysin-encoding gene of Lactobacillus bulgaricus bacteriophage mv1. Gene 94, 61-67.

Bolivar, F., Rodriguez, R. I., Greene, P. J., Betlach, M. C., Heynecker, H. L., Boyer, H. W., Crosa, J. H. \& Falkow, S. (1977). Construction and characterization of new cloning vehicles, II. A multipurpose cloning system. Gene 2, 95-113.

Boyer, H. W. \& Roulland-Dussoix, D. A. (1969). A complementation analysis of the restriction and modification of DNA in Escherichia coli. Journal of Molecular Biology 41, 459-470.

CAMPBell, A. M. (1962). Episomes. Advances in Genetics 11, 101-145.

Casjens, S., Huang, W. M., Hayden, M. \& ParR, R. (1987). Initiation of bacteriophage P22 DNA packaging series: analysis of a mutant that alters the DNA target specificity of the packaging apparatus. Journal of Molecular Biology 194, 411-422.

Chelata, C. A. \& Margolin, P. (1974). Effects of deletions on cotransduction linkage in Salmonella typhimurium. Evidence that bacterial chromosome deletions affect the formation of transducing DNA fragments. Molecular and General Genetics 131, 97-112.

Cluzel, P. J., Veaux, M., Rousseau, M. \& Accolas, J. P. (1987). Evidence for temperate bacteriophages in two strains of Lactobacillus bulgaricus. Journal of Dairy Research 54, 397-405.

Deichelbohrer, I., MesSer, W. \& TRAUTNER, T. A. (1982). Genome of Bacillus subtilis bacteriophage SPP1, structure and nucleotide sequence of pac, the origin of DNA packaging. Journal of Virology 41, 83-90.

De Man, J. C., Rogosa, M. \& Sharpe M. E. (1960). A medium for cultivation of Lactobacilli. Journal of Applied Bacteriology 23, 130135.

FeinberG, A. P. \& Vogelstein, B. (1983). A technique for radiolabelling DNA restriction endonuclease fragments to high specific activity. Analytical Biochemistry 132, 6-13.

Hottinger, H., Ohgi, T., Zwahlen, M.-C., Dhamija, S. \& Soll, D. (1987). Allele-specific complementation of an Escherichia coli leuB mutation by a Lactobacillus bulgaricus tRNA gene. Gene 60, 149-152.

JACKSON, E. N., JACKSON, D. A. \& DEANS, R. J. (1978). EcoRI analysis of bacteriophage P22 DNA packaging. Journal of Molecular Biology 118, 365-388.

Johnson, D. A., Gaustch, J. W., Sportsman J. R. \& Elder, J. H. (1984). Improved technique utilizing nonfat dry milk for analysis of proteins and nucleic acids transferred to nitrocellulose. Gene Analytical Technology 1, 3-8.

JusT, W. \& KLOTZ, G. (1990). Terminal redundancy and circular permutation of mycoplasma virus L3 DNA. Journal of General Virology 71, 2157-2162.

KANDLER, O. \& WeISS, N. (1986). Regular, nonsporing Gram-positive rods. In Bergey's Manual of Systematic Bacteriology, vol. 2, pp. 12081260. Edited by P. H. A. Sneath, N. S. Mair, M. E. Sharpe and J. G. Holt. Baltimore: Williams \& Wilkins.

Langella, P. \& Chopin, A. (1987). Conjugal transfer of plasmid pIP501 from Lactococcus lactis to Lactobacillus delbrueckii subsp. bulgaricus and Lactobacillus helveticus. FEMS Microbiology Letters 60, 149-152.

Lahbib-Mansais, Y., Mata, M. \& RitzenthaleR, P. (1988). Molecular taxonomy of Lactobacillus phages. Biochimie 70, 429-435.

Lakshmidevi, G., Davidson, B. E. \& Hillier, A. J. (1988). Circular permutation of the genome of a temperate bacteriophage from Streptococcus cremoris BK5. Applied and Environmental Microbiology 54, 1039-1045.

Le Bourgeois, P., Mata, M. \& Ritzenthaler, P. (1989). Genome comparison of Lactococcus strains by pulsed-field gel electrophoresis. FEMS Microbiology Letters 59, 65-70.
MCClelland, M., Jones, R., Patel, Y. \& Nelson, M. (1987) Restriction endonucleases for pulsed field mapping of bacterial genomes. Nucleic Acids Research 15, 5985-6005.

MASTERS, M. (1985). Generalized transduction. In The Genetics of Bacteria, pp. 197-215. Edited by J. G. Scaife, D. Leach, and A. Galizzi. New York: Academic Press.

Mata, M., Trautwetter, A., Luthaud, G. \& Ritzenthaler, P. (1986). Thirteen virulent and temperate bacteriophages of Lactobacillus bulgaricus and Lactobacillus lactis belong to a single DNA homology group. Applied and Environmental Microbiology 52, 812818.

MEAD, D. A., Szczesna, E \& KEMPER, B. (1986). Single-stranded DNA 'blue'T7 promoter plasmids: a versatile tandem promoter system for cloning and protein engineering. Protein Engineering 1, 67-74.

MINTON, N. P. (1984). Improved plasmid vectors for the isolation of translational lac gene fusions. Gene 31, 269-273.

Mollet, B. \& Delley, M. (1990). Spontaneous deletion formation within the $\beta$-galactosidase gene of Lactobacillus bulgaricus. Journal of Bacteriology 172, 5670-5676.

MOLLET, B. \& DELlEY, M. (1991). A $\beta$-galactosidase deletion mutant of Lactobacillus bulgaricus reverts to generate an active enzyme by internal DNA sequence duplication. Molecular and General Genetics 227, 17-21.

PitTet, A. C. \& HotTInger, H. (1989a). Sequence of a hexameric tRNA gene cluster associated with rRNA genes in Lactobacillus bulgaricus. Nucleic Acids Research 17, 4873.

PitTeT, A. C. \& HotTInger, H. (1989b). A Lactobacillus bulgaricus DNA fragment containing a 5S RNA gene adjacent to a pentameric tRNA gene cluster. Nucleic Acids Research 17, 4874.

ReED, K. C. \& MANN, D. A. (1985). Rapid transfer of DNA from agarose gels to nylon membranes. Nucleic Acids Research 13, 72077221

Rigby, P. W., Dieckman, M., Rhodes, C. \& Berg, P. (1977). Labelling deoxyribonucleic acid to high specific activity in vitro by nick translation with DNA polymerase I. Journal of Molecular Biology 113, 237-251.

RusSel, M. \& MODEL, P. (1984). Replacement of the fip gene of E. coli by an inactive gene cloned on a plasmid. Journal of Bacteriology 159, $1034-1039$.

Sambrook, J., Fritsch, E. F. \& Maniatis, T. (1989). Molecular Cloning: a Laboratory Manual, 2nd edn. Cold Spring Harbor, NY: Cold Spring Harbor Laboratory.

Schmidt, B. F., Adams, R. M., Requadt, C., Power, S. \& Mainzer, S. E. (1989). Expression and nucleotide sequence of the Lactobacillus bulgaricus $\beta$-galactosidase gene cloned in Escherichia coli. Journal of Bacteriology 171, 625-635.

SCHÖN, A., HotTINGER, H. \& SolL, D. (1988). Misaminoacylation and transamidation are required for protein biosynthesis in Lactobacillus bulgaricus. Biochimie 70, 391-394.

SOUTHERN, E. M. (1975). Detection of specific sequences among DNA fragments separated by gel electrophoresis. Journal of Molecular Biology 98, 503-517.

SterNBERG, N. \& Coulby, J. (1987). Recognition and cleavage of the bacteriophage P1 packaging site (pac). I. Differential processing of the cleaved ends in vivo. Journal of Molecular Biology 194, 453-468.

TABOR, S. \& RichaRdSON, C. (1985). A bacteriophage T7 RNA polymerase promoter system for controlled exclusive expression of specific genes. Proceedings of the National Academy of Sciences of the United States of America 82, 1074-1078.

Trautwetter, A., Ritzenthaler, P., Alatossava, T. \& MataGILSINGER, M. (1986). Physical and genetic characterization of the genome of Lactobacillus lactis bacteriophage LL-H. Journal of Virology 59, 551-555.

WATERbURY, P. G. \& LANE, M. J. (1987). Generation of lambda phage concatemers for use as pulsed field electrophoresis size markers. Nucleic Acids Research 15, 3930.

WEAVER, S. \& LEVINE, M. (1977). Recombinational circularization of Salmonella phage P22 DNA. Virology 76, 29-38. 